\title{
CEE LABOUR MARKETS - HOMOGENEITY OR DIVERSITY?
}

\author{
Ewa ROLLNIK-SADOWSKA (iD*, Marta JAROCKA \\ Faculty of Engineering Management, Bialystok University of Technology, Bialystok, Poland
}

Received 07 October 2020; accepted 28 February 2021; first published online 05 July 2021

\begin{abstract}
The aim of the article is to assess real changes taking place on CEE labour markets over the last fifteen years, taking into account as the initial point of analysis - 2004, i.e. the moment of extension of the EU by the first CEE countries and as a final point of analysis - 2019. The research was conducted in two stages. The authors made comparisons with the use of the TOPSIS method, which allowed for creating rankings of CEE countries in terms of labour market situation in the analysed years. The second stage of the study involved the analysis of relations between employment and GDP by an estimation of the multiple regression model. The conducted analysis proves that CEE countries are diversified when it comes to the labour market situation. These countries are also characterized by significant dynamics of changes in the labour market.
\end{abstract}

Keywords: CEE countries, labour market, TOPSIS method, regression model.

JEL Classification: E24, F02, J21, J64.

\section{Introduction}

Central and Eastern European (CEE) countries represented comparable socio-economic conditions as they experienced centrally planned management and instituting systemic change. Those economies, entering the transition period, faced problems of fall at the level of economic activity and, as a result, a decrease in employment and an emergence of cyclical and structural unemployment. The process of implementation of market economy required the initiating of comprehensive reforms. The transition of most CEE countries has shown a significant progress, which was appreciated by international institutions (Rollnik-Sadowska, 2016). A group of CEE economies constituting Czechia, Estonia, Latvia, Lithuania, Hungary, Poland, Slovakia and Slovenia joined the European Union in 2004. In 2007 the EU was extended by two more CEE countries - Bulgaria and Romania. Finally, in 2013 Croatia joined the EU. All those countries gained access to additional funds to bridge development differences and took part in the cohesion policy. They all noticed significant social and economic development, which influenced the labour market situation.

\footnotetext{
${ }^{\star}$ Corresponding author. E-mail: e.rollnik@pb.edu.pl
} 
The aim of the article is to assess real changes taking place on CEE labour markets over the last fifteen years, taking into account as the initial point of analysis - 2004, i.e. the moment of extension of the EU by the first CEE countries and as a final point of analysis - 2019 . To assess the initial and current situation on CEE labour markets, the authors used diagnostic variables obtained from Eurostat resources, including measures characterizing the situation on the labour market diagnosing the situation in CEE countries. The identified set of variables was used to create a synthetic indicator reflecting the situation on labour markets in selected European countries as a derivative of the condition of the economy. In order to conduct a comparative analysis of CEE labour markets, the authors made rankings of countries for the two analysed periods (2004 and 2019) with the use of the TOPSIS method. Based on the results obtained by means of this method, they presented diverse CEE labour markets in a spatial arrangement.

The next stage of the study involved an estimation of the multiple regression model, which explains how the identified factors (determinants) affect the position of CEE countries in the context of their employment potential. The employment rate was adopted as a dependent variable, while GDP is considered as independent variable.

The rest of the paper is organised as follows. In the next section the authors discuss major concepts explaining the peculiarities of CEE labour markets. Then they present the methodology of presenting the diversity of CEE labour markets using taxonomic methods. The subsequent section includes regression analysis of employment in CEE countries. The last section concludes with a summary of the main findings as well as macroeconomic policy implications of the paper.

\section{Peculiarities of CEE labour markets}

Nowadays, after thirty years of transition, post-socialist countries can be treated as much more diversified in terms of economic performance and institutional framework than they were at the beginning of the transition process (Pilc, 2015). The reason is that those countries went through different paths of economic reforms. It also concerns the labour market situation as significant changes have been implemented on Central and Eastern European labour markets both in the transition period and after that time.

CEE countries chose different pathways of social and economic reforms already in the transition process. Poland, the Czech Republic, Slovakia, Estonia, Latvia, Lithuania are often seen as economies representing the shock therapy model. Hungary and Slovenia trod more cautiously, in part because they had more liberalized economies at the start of their transition and less of a need for rapid change. Hence, their transition processes can be treated more as examples of the gradualist model (Roaf et al., 2014; Veebel et al., 2014).

With the advent of the capitalist market in transition economies, there was noticed a significant fall in demand coming simultaneously from various sources, which was translated into a sharp fall in GDP and an even sharper one in industrial production (Fedajev et al., 2019). The demand fall caused substantial decreases in employment and economic activity levels as well as in the occurrence of informal employment (Cazes \& Nesporova, 2003). This fall in output, with a lag, was also reflected in the appearance of transition cyclical unemployment resulting from the reduced level of economic activity (Winiecki, 2008). Moreover, 
transition economies were characterized by a significant excess supply of low-skilled workers (demanded in generally heavy-industry oriented socialist economies) and by a growing demand for better skilled prospective employees having qualifications more suitable for serviceand consumer-oriented market economy (Winiecki, 2008). Therefore, in order to adapt to these changes, governments in post-socialist countries had to substantially reform the labour market institutional framework.

Within the structural adjustment package, introducing employment flexibility and lowering social protection were in most cases offered as the sole means with which to transform labour markets in the new market conditions. Amended national labour legislation, newly established public employment services and labour market policies have facilitated these changes by reducing high employment protection in existing jobs inherited from the previous regime (Cazes \& Nesporova, 2003).

During the transition period, the CEE countries gradually implemented reductions in the duration and amount of unemployment benefits as well as tightened eligibility criteria (de Koning, 2007). Moreover, the labour market policy (e.g. in terms of wage negotiations) became more decentralized and minimum wages were decreased. In the frame of macroeconomic policy, some CEE countries (e.g. Slovenia, Estonia, the Czech Republic - Brejc \& Diamantopoulou, 2000; Sikulova \& Frank, 2014) attracted foreign investors, provided economic incentives for job creating projects and re-oriented the economic activity from industrial production to services. After the regime change some CEE countries, e.g. Slovakia and Poland, implemented industrial and corporative structural reconstruction which caused higher labour productivity (Lipták, 2013).

The situation on labour markets in the transition countries of Central and Eastern Europe has been determined by social-economic changes influencing both labour demand and labour supply. They include, inter alia, the level of market-orientation of the economy (implemented mainly by the privatization of state-owned companies and enterprise restructuring - Pilc, 2015), fiscal and monetary policy, investments in public infrastructure (e.g. transportation infrastructure), the level of expenditures on social benefits.

In order to accommodate the new labour market demands, CEE countries had to adjust their policies not only to new economic conditions but also to demands resulting from preparation for the EU membership. They had to adapt their employment systems so as to be able to implement the European Employment Strategy. EU concepts and policies differed significantly from the social policy of transition countries. They are expressions of consensus reached between fifteen old EU member states based on decades of welfare development (Szalai, 2002). However, the eleven CEE transition countries, analysed in this paper, met these criteria and joined the EU. It is worth elaborating on the following question: have the countries with comparable social and economic background maintained homogenous or diversified conditions on the labour markets?

As data shows, CEE countries entered the EU with a diversified level of unemployment rate - Tables 1, 2. In 2004 the indicator ranged from 19\% in Poland and 18.2\% in Slovakia to $6.1 \%$ in Hungary and $6.3 \%$ in Slovenia. Fifteen years of participation in the EU brought significant drops of the unemployment rate in all of the analysed countries. However, those decreases also differed to significant extent, varying from $83 \%$ in Poland to $29 \%$ in Slovenia, as evidenced by the range of these values (in Poland $-15.7 \%$ and in Slovenia $-4.2 \%$ ). 
Table 1. Unemployment rate in CEE countries (2004-2019)

\begin{tabular}{|c|c|c|c|c|c|c|c|c|c|c|c|}
\hline Year & 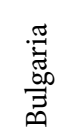 & $\begin{array}{l}. \frac{\pi}{\mathcal{U}} \\
\stackrel{\mathbb{N}}{N}\end{array}$ & 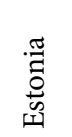 & $\begin{array}{l}\stackrel{\mathscr{J}}{\widetilde{J}} \\
\stackrel{0}{U}\end{array}$ & $\underset{\stackrel{\pi}{\leftrightarrows}}{\stackrel{\pi}{\leftrightarrows}}$ & $\begin{array}{l}. \stackrel{\Xi}{\Xi} \\
\text { 芯 } \\
\text { 志 }\end{array}$ & 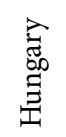 & $\begin{array}{l}\vec{\Xi} \\
\frac{\vec{\pi}}{0} \\
\text { م. }\end{array}$ & 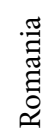 & 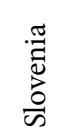 & $\frac{\vec{z}}{\frac{\vec{z}}{\tilde{\sigma}}}$ \\
\hline 2004 & 12.1 & 8.3 & 10.1 & 13.7 & 11.7 & 10.9 & 6.1 & 19 & 8.1 & 6.3 & 18.2 \\
\hline 2005 & 10.1 & 7.9 & 8 & 12.7 & 10 & 8.3 & 7.2 & 17.8 & 7.2 & 6.5 & 16.3 \\
\hline 2006 & 9 & 7.2 & 5.9 & 11.3 & 7 & 5.8 & 7.5 & 13.9 & 7.3 & 6 & 13.4 \\
\hline 2007 & 6.9 & 5.3 & 4.6 & 9.9 & 6.1 & 4.3 & 7.4 & 9.6 & 6.4 & 4.9 & 11.1 \\
\hline 2008 & 5.6 & 4.4 & 5.5 & 8.6 & 7.7 & 5.8 & 7.8 & 7.1 & 5.8 & 4.4 & 9.5 \\
\hline 2009 & 6.8 & 6.7 & 13.5 & 9.2 & 17.5 & 13.8 & 10 & 8.2 & 6.9 & 5.9 & 12 \\
\hline 2010 & 10.3 & 7.3 & 16.7 & 11.7 & 19.5 & 17.8 & 11.2 & 9.7 & 7 & 7.3 & 14.4 \\
\hline 2011 & 11.3 & 6.7 & 12.3 & 137 & 16.2 & 15.4 & 11 & 9.7 & 7.2 & 8.2 & 13.6 \\
\hline 2012 & 12.3 & 7 & 10 & 16 & 15 & 13.4 & 11 & 10.1 & 6.8 & 8.9 & 14 \\
\hline 2013 & 13 & 7 & 8.6 & 17.3 & 11.9 & 11.8 & 10.2 & 10.3 & 7.1 & 10.1 & 14.2 \\
\hline 2014 & 11.4 & 6.1 & 7.4 & 17.3 & 10.8 & 10.7 & 7.7 & 9 & 6.8 & 9.7 & 13.2 \\
\hline 2015 & 9.2 & 5.1 & 6.2 & 16.2 & 9.9 & 9.1 & 6.8 & 7.5 & 6.8 & 9 & 11.5 \\
\hline 2016 & 7.6 & 4 & 6.8 & 13.1 & 9.6 & 7.9 & 5.1 & 6.2 & 5.9 & 8 & 9,7 \\
\hline 2017 & 6.2 & 2.9 & 5.8 & 11.2 & 8.7 & 7.1 & 4.2 & 4.9 & 4.9 & 6.6 & 8.1 \\
\hline 2018 & 5.2 & 2.2 & 5.4 & 8.5 & 7.4 & 6.2 & 3.7 & 3.9 & 4.2 & 5.1 & 6.5 \\
\hline 2019 & 4.2 & 2 & 4.4 & 6.6 & 6.3 & 6.3 & 3.4 & 3.3 & 3.9 & 4.5 & 5.8 \\
\hline
\end{tabular}

Table 2. Statistical measures related to unemployment rate in CEE countries (2004-2019)

\begin{tabular}{|c|c|c|c|c|c|c|c|c|c|c|c|}
\hline $\begin{array}{l}\text { Statistical } \\
\text { measures }\end{array}$ & 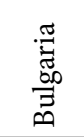 & 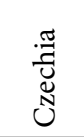 & 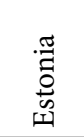 & 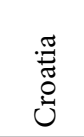 & 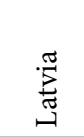 & 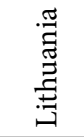 & $\begin{array}{l}\widehat{\vec{心}} \\
\text { 总 } \\
\text { 至 }\end{array}$ & 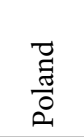 & 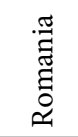 & $\begin{array}{l}. \frac{9}{0} \\
\frac{0}{0} \\
\frac{0}{\omega}\end{array}$ & $\begin{array}{l}\frac{\pi}{3} \\
\frac{\pi}{\tilde{\sigma}} \\
\frac{\sigma}{\omega}\end{array}$ \\
\hline $\begin{array}{l}\text { Coefficient } \\
\text { of variation }\end{array}$ & $33 \%$ & $39 \%$ & $43 \%$ & $27 \%$ & $37 \%$ & $39 \%$ & $34 \%$ & $58 \%$ & $19 \%$ & $26 \%$ & $31 \%$ \\
\hline Max & 13 & 8.3 & 16.7 & 17.3 & 19.5 & 17.8 & 11.2 & 19 & 8.1 & 10.1 & 18.2 \\
\hline Min & 4.2 & 2 & 4.4 & 6.6 & 6.1 & 4.3 & 3.4 & 3.3 & 3.9 & 4.4 & 5.8 \\
\hline Range & 8.8 & 6.3 & 12.3 & 10.7 & 13.4 & 13.5 & 7.8 & 15.7 & 4.2 & 5.7 & 12.4 \\
\hline $\begin{array}{l}\text { Relative change } \\
\text { (base: 2004) }\end{array}$ & $-65 \%$ & $-76 \%$ & $-56 \%$ & $-52 \%$ & $-46 \%$ & $-42 \%$ & $-44 \%$ & $-83 \%$ & $-52 \%$ & $-29 \%$ & $-68 \%$ \\
\hline
\end{tabular}

The highest unemployment rate in the analysed period was observed in Latvia (19.5\%) and Poland (19\%), and the lowest - in Czechia (2\%). The highest value of the coefficient of variation was also recorded in Poland (58\%), therefore the value of the unemployment rate in this country showed the greatest changes.

Moreover, the difference between the highest and the lowest value of unemployment rate also differed significantly in the analysed CEE countries - Figure 1 . The range was the highest in Poland, the country with the top relative change. The improving economic situation in Poland and as a result better labour market situation was influenced by the financing of the 


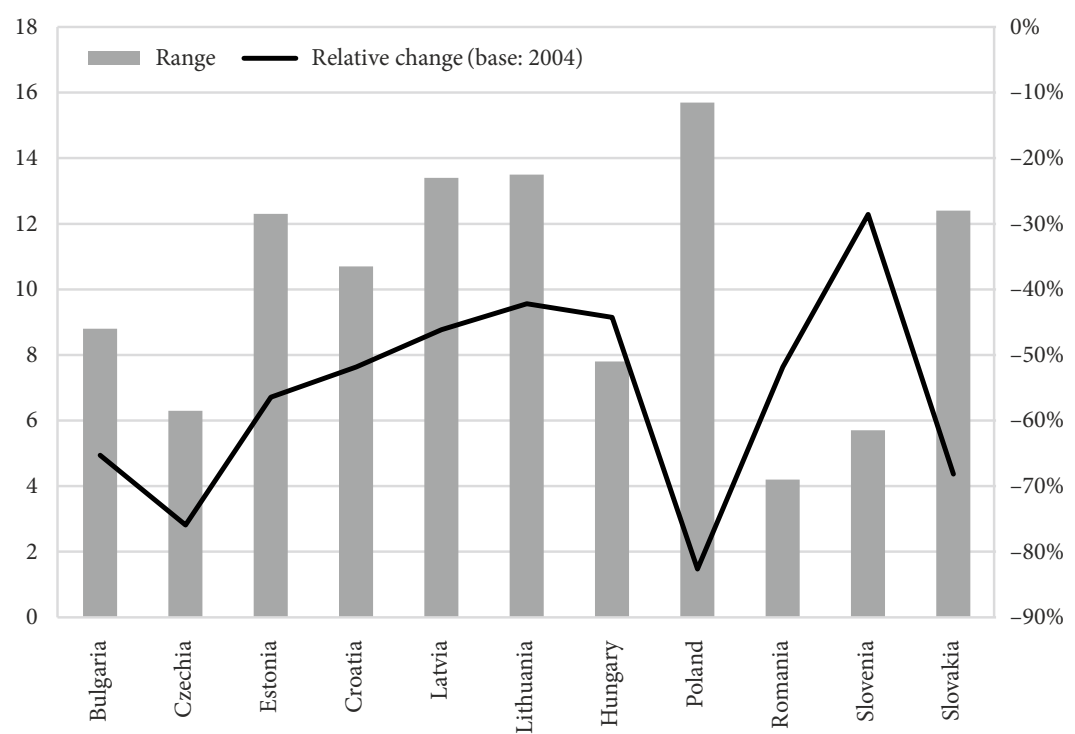

Figure 1. Range and relative change of unemployment rate in CEE countries for years 2004-2019

European Union, mainly in terms of improving road infrastructure. Household consumption and gradually increasing investment, in particular public investment supported by EU funds, remained the main drivers of GDP growth in Poland (Rollnik-Sadowska, 2014; European Commission, 2019). The lowest range of unemployment rate was in Romania, the country that has benefited from the support of the European Union only since 2007. That country is much more behind schedule in terms of involvement in the labour market in services (still below 50\% share) despite the gradual catching up in terms of revenues from the service sector (Novák, 2020).

The unemployment rate is one of the basic labour market indicator but it does exhaust the complexity of measures describing the situation on the labour market. To meet the main objective of the paper and to assess real changes taking place on CEE labour markets over the last fifteen years, the authors implemented the below described methodology using taxonomic and econometric methods.

\section{Methodology}

With a view to achieving the research objective, which is assessing changes on labour markets in CEE countries in the years 2004-2019, the research method was adjusted to the adopted assumptions.

The research was conducted in two stages. The authors' aim was to compare changes on labour markets in CEE countries over 15 years. For the border years the authors assumed the first year of extension of the EU by CEE countries in 2004 and the final point of analysis - 2019, when all selected CEE countries implemented the EU cohesion policy, deriving benefits from its advantages. 
Comparisons were made by constructing two rankings of CEE countries. The first one concerned the situation on the labour market in the countries in 2004, the second - the situation on labour markets in 2019. The authors made comparisons with the use of the TOPSIS method, which allowed for creating rankings of CEE countries in terms of labour market situation in the analysed years. The construction of rankings was preceded by a substantive and statistical selection of diagnostic features. In order to examine the diversity of labour market situation in CEE countries, the authors prepared an initial list of diagnostic features which included 7 variables. The list was prepared on the basis of expert analysis of available statistical data and the knowledge of factors determining the situation on the CEE countries' labour market.

As part of the statistical selection of characteristics, a set of potential diagnostic variables developed by the authors was verified with regard to their informative value. Source literature assumes that the set of criterion values should exclude those which are characterized by low discriminating ability or duplicate information carried by other features. The classic coefficient of variation was used to assess the discriminatory capacity of traits (Młodak, 2006). It was assumed that those for which the coefficient of variation is lower than $10 \%$ will be eliminated from the potential set of diagnostic traits. In order to investigate the correlation between variables, a correlation matrix was determined. Excessive correlation between the traits may indicate that they cause redundancy of description (Giudici, 2003). Therefore, the threshold level of Pearson's linear correlation coefficient was assumed $\left(r^{*}=0.9\right)$ (Strzała \& Przechlewski, 1994). In literature, there are also different positions in the correlation of diagnostic features. According to Kukuła (2000), in building rankings, correlations between variables - even high ones - do not have to disturb each other. Therefore, in the process of reducing the dimension of the set of diagnostic features, apart from their statistical properties, the researcher's substantive knowledge about the analysed phenomenon is also important.

Next, on the basis of the values of selected factors characterizing the analysed CEE countries, the authors created rankings of countries. For this purpose, one of the linear ordering methods was used - the TOPSIS method (a technique for order performance by similarity to ideal solution), which allows to build the ranking of alternatives based on the shortest distance from the positive ideal solution and the farthest from the negative ideal solution (Hwang \& Yoon, 1981). This method is also used in labour market research, e.g. in works of Ertman (2011), Pietrzak (2016), Mohaghar et al. (2018), Džunić et al. (2018), Stanimir (2020). In the research, various normalization methods, distance measures and aggregation operators can be used (Shih et al., 2007). In this paper, vector normalization was used according to the formula:

$$
r_{i j}=\frac{x_{i j}}{\sqrt{\sum_{i=1}^{m} x_{i j}^{2}}}, i=1, \ldots, m, j=1, \ldots, n .
$$

On the basis of the matrix of standardized diagnostic traits, the ideal $\left(\mathrm{A}^{*}\right)$ and negative ideal solutions ( $\left.A^{\prime}\right)$ were determined, based on the formula (Behzadian et al., 2012):

$$
\begin{aligned}
& \mathrm{A}^{*}=\left\{v_{1}^{*}, \ldots, v_{n}^{*}\right\}, \text { where } v_{i}^{*}=\left\{\max \left(v_{i j}\right) \text { if } j \in J ; \min \left(v_{i j}\right) \text { if } j \in J^{\prime}\right\}, \\
& \mathrm{A}^{\prime}=\left\{v_{1}^{\prime}, \ldots, v_{n}^{\prime}\right\}, \text { where } v_{i}^{\prime}=\left\{\min \left(v_{i j}\right) \text { if } j \in J ; \max \left(v_{i j}\right) \text { if } j \in J^{\prime}\right\} .
\end{aligned}
$$


Then, separation measures for each alternative were calculated. The distance from the positive ideal alternative is:

$$
S_{i}^{*}=\sqrt{\sum\left(v_{j}^{*}-v_{i j}\right)^{2}},
$$

and the distance from the negative ideal alternative is:

$$
S_{i}^{\prime}=\sqrt{\sum\left(v_{j}^{\prime}-v_{i j}\right)^{2}}
$$

After determining the synthetic measures according to the formula:

$$
C_{i}^{*}=\frac{S_{i}^{\prime}}{S_{i}^{*}+S_{i}^{\prime}}
$$

the authors created ranking lists of CEE countries.

In order to compare the rankings obtained in the survey of 2004 and 2019, the authors determined and interpreted changes in the positions of CEE countries in the rankings over 15 years, and calculated the Spearman's Rank correlation coefficient between the results of the rankings.

Then, an attempt was made to divide the analysed countries (the structure of their rating) into homogeneous groups in terms of labour market development. For this purpose, the authors used one of the methods of classification of linearly ordered objects which is based on two parameters (arithmetic mean and standard deviation). The counties were categorized into four groups, depending on the allocation of the value of their synthetic feature $C_{i}^{*}$ :

group I, when: $C_{i}^{*} \geq \overline{C_{i}^{*}}+S_{C_{i}^{*}}$,

group II, when: $\overline{C_{i}^{*}}<C_{i}^{*} \leq \overline{C_{i}^{*}}+S_{C_{i}^{*}}$,

group III, when: $\overline{C_{i}^{*}}-S_{C_{i}^{*}} \leq C_{i}^{*} \leq \overline{C_{i}^{*}}$,

group IV, when: $C_{i}^{*}<\overline{C_{i}^{*}}-S_{C_{i}^{*}}$.

Among the countries groups created in this way, group I is characterized by the best situation on the labour market, and group IV by the worst situation on the labour market in terms of the analysed variables.

The second stage of the study involved the analysis of relations between employment and GDP. GDP is an important determinant of labour market situation (Revenga \& Bentolila, 1995). That stage allowed for deepening the analysis of diversification of CEE labour markets. In order to examine the relationship between employment and GDP, the model proposed by Kotlorz and Sojka (2017) was used, the starting point of which was the equation of labour demand:

$$
\ln \left(E_{t}\right)=\gamma+\alpha t+\beta \ln \left(Y_{t}\right)
$$

where: $E_{t}$ - number of persons employed in the economy in period $t ; Y_{t}-$ GDP in period $t$; $t$ - time variable; $\gamma$ - intercept; $\alpha$ - medium-term pace of increase or decrease in the number of employed, resulting from the impact of other factors determining changes in the number of employed than GDP; $\beta$ - elasticity of labour demand in relation to real GDP. 
While proceeding with calculating the first differences of Equation (5), the expression given by the formula (6) can be obtained:

$$
\Delta \ln \left(E_{t}\right)=\alpha+\beta \Delta \ln \left(Y_{t}\right)
$$

where:

$$
\Delta \ln \left(E_{t}\right) \approx \frac{\Delta E_{t}}{E_{t-1}} \equiv S_{E}
$$

is the employment growth rate and

is the GDP growth rate.

$$
\Delta \ln \left(Y_{t}\right) \approx \frac{\Delta Y_{t}}{Y_{t-1}} \equiv S_{Y_{t}}
$$

Based on Equations (5) and (6), the following model was formulated:

$$
S_{E_{t}}=\alpha+\beta S_{Y_{t}}+\varepsilon_{t}
$$

where: $S_{E_{t}}, S_{Y_{t}}$ - employment and GDP growth rate in period $t ; \alpha$ - hypothetical pace of changes in the number of employed with zero GDP growth; $\beta$ - elasticity of the number of employed in relation to GDP; $\xi$ - random component of the model.

In this study, 11 simple linear regression models of the form (9) were estimated for all analysed CEE countries. The estimation was performed on quarterly data for the years 2004-2019. After estimating the structural parameters of the models, their verification was performed: errors in parameter estimation were determined, the significance of the estimated parameters was tested (Student's $t$-test), the statistical significance of the models was checked ( $F$ test) and the values of the determination coefficients $\left(R^{2}\right)$ were determined.

\section{Taxonomic analysis of CEE labour markets}

The conducted research indicates significant differences between individual CEE countries both in 2004 and 2019. The assessment of the diversity of the analysed countries in terms of labour market development, carried out with the use of the TOPSIS method, allowed for international comparisons and observations of changes over time. Variables accepted for analysis:

$\mathrm{X} 1$ - employment rate

$\mathrm{X} 2$ - unemployment rate,

$\mathrm{X} 3$ - long-term unemployment rate,

$\mathrm{X} 4$ - youth long-term unemployment rate,

$\mathrm{X} 5$ - inactive population as a percentage of the total population,

X6 - NEET rate,

X7 - labour productivity per person employed and hours worked (EU27_2020 = 100, \%).

According to the assumed research methodology, a statistical selection of diagnostic features was made. The values of coefficients of variation and correlation matrix between diagnostic variables are presented in Table 3. 
Table 3. Values of coefficients of variation and correlation matrix between diagnostic variables (2004, 2019)

\begin{tabular}{|c|c|c|c|c|c|c|c|}
\hline Year & \multicolumn{7}{|c|}{2004} \\
\hline Variable & X1 & X2 & X3 & X4 & X5 & X6 & X7 \\
\hline Coefficient of variation & $7.5 \%$ & $38.1 \%$ & $50.2 \%$ & $48.5 \%$ & $11.5 \%$ & $33.6 \%$ & $24.2 \%$ \\
\hline X1 & 1 & - & - & - & - & - & - \\
\hline X2 & -0.547 & 1 & - & - & - & - & - \\
\hline X3 & -0.584 & 0.954 & 1 & - & - & - & - \\
\hline X4 & -0.695 & 0.883 & 0.931 & 1 & - & - & - \\
\hline X5 & -0.816 & -0.016 & 0.032 & 0.201 & 1 & - & - \\
\hline X6 & -0.673 & 0.278 & 0.339 & 0.491 & 0.627 & 1 & - \\
\hline X7 & 0.321 & -0.087 & 0.049 & -0.096 & -0.438 & -0.555 & 1 \\
\hline Year & & & \multicolumn{7}{|c|}{2019} & & & \\
\hline Variable & X1 & X2 & X3 & X4 & X5 & X6 & X7 \\
\hline Coefficient of variation & $5.4 \%$ & $32.0 \%$ & $49.4 \%$ & $57.5 \%$ & $15.4 \%$ & $30.4 \%$ & $13.5 \%$ \\
\hline X1 & 1 & - & - & - & - & - & - \\
\hline X2 & -0.314 & 1 & - & - & - & - & - \\
\hline X3 & -0.401 & 0.753 & 1 & - & - & - & - \\
\hline X4 & -0.696 & 0.410 & 0.817 & 1 & - & - & - \\
\hline X5 & -0.956 & 0.025 & 0.204 & 0.624 & 1 & - & - \\
\hline X6 & -0.694 & 0.154 & 0.423 & 0.780 & 0.694 & 1 & - \\
\hline X7 & 0.243 & -0.100 & -0.339 & -0.487 & -0.233 & -0.725 & 1 \\
\hline & & & & & & \\
\hline & & & & - & - \\
\hline & & & & - & - & - \\
\hline
\end{tabular}

The analysis of variability shows that six analysed features (X2-X7) are characterized by a high degree of diagnostics. In the situation of high degree of diagnostics, the values of coefficients of variation are greater than $10 \%$. Only in the case of X1, a low degree of variation was observed (less than 10\%), which means that the variable does not differentiate the analysed countries. Hence, it was decided to remove X1 from the set of diagnostic features.

Disregarding strong correlations of variables X2, X3 and X4, the authors decided to include all of them in the analysis. Taking into account the unemployment rate itself does not allow for capturing the specificity of the phenomenon of unemployment, which is often long-term or indicates a particularly difficult situation of selected groups, especially young people (Hutengs \& Stadtmann, 2014).

On the basis of the adopted set of six diagnostic features, rankings of CEE countries were built with the use of the TOPSIS method. The ranking lists obtained for 2004 and 2019 are presented in Table 4.

In 2004, the best situation on the labour market was in Slovenia. That country was distinguished by one of the lowest unemployment rates (including long-term unemployment) and by far the highest labour productivity per person employed.

Five countries were included in the second rating group, i.e. Hungary, Czechia, Estonia, Lithuania and Latvia. The third group was composed of Romania, Croatia and Bulgaria. 
Table 4. Rankings of CEE countries with regard to labour market situation in 2004 and 2019

\begin{tabular}{|c|c|c|c|c|c|}
\hline \multirow[b]{2}{*}{ Position } & \multicolumn{2}{|c|}{ Ranking 2004} & \multicolumn{2}{|c|}{ Ranking 2019} & \multirow{2}{*}{$\begin{array}{c}\text { Changing } \\
\text { position } \\
\text { in the ranking }\end{array}$} \\
\hline & Country & $\begin{array}{l}\text { Synthetic } \\
\text { variable }\end{array}$ & Country & $\begin{array}{c}\text { Synthetic } \\
\text { variable }\end{array}$ & \\
\hline 1 & Slovenia & 0.934 & Czechia & 0.968 & -4 \\
\hline 2 & Hungary & 0.824 & Poland & 0.809 & -2 \\
\hline 3 & Czechia & 0.812 & Estonia & 0.802 & +2 \\
\hline 4 & Estonia & 0.751 & Hungary & 0.678 & +1 \\
\hline 5 & Lithuania & 0.748 & Slovenia & 0.623 & -1 \\
\hline 6 & Latvia & 0.730 & Lithuania & 0.592 & -1 \\
\hline 7 & Romania & 0.610 & Latvia & 0.467 & -1 \\
\hline 8 & Croatia & 0.431 & Romania & 0.397 & -2 \\
\hline 9 & Bulgaria & 0.417 & Bulgaria & 0.324 & 0 \\
\hline 10 & Poland & 0.303 & Croatia & 0.289 & +8 \\
\hline 11 & Slovakia & 0.294 & Slovakia & 0.231 & 0 \\
\hline
\end{tabular}

Legend:

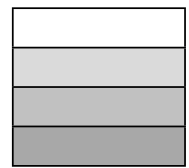

$1^{\text {st }}$ rating group of CEE countries;

$2^{\text {nd }}$ rating group of CEE countries;

$3^{\text {rd }}$ rating group of CEE countries;

$4^{\text {th }}$ rating group of CEE countries.

In 2004, the worst labour marked situation was observed in Poland and Slovakia as in those CEE countries, belonging to the last, fourth rating group, the worst or one of the worst values of all analysed variables were recorded. Poland represented the highest youth longterm unemployment rate, while Slovakia reached the highest unemployment rate (including long-term unemployment).

After 15 years, the situation on the labour market of all CEE countries improved. It could be due to, among other things, an increase in foreign direct investment, which has been a source of productivity. Both capital deepening and skills upgrades have the potential to strengthen productivity growth (European Commission, 2019). At the same time, in comparison to 2004, the ranking position of the majority of analysed CEE countries (excluding Slovakia and Bulgaria, where the position remained unaltered) changed significantly. This is evidenced by a high value of Spearman's rank correlation coefficient between the ranking results, which is at the level of 0.564. In 2019 the first rating group was joined by Czechia, Poland and Estonia. Poland was the one which improved its rating position the most out of all analysed CEE countries - by 8 points. It was mainly due to a significant drop in unemployment rate (by 16 p.p.), including long-term unemployment by 10 p.p. and youth longterm unemployment by 13 p.p. Czechia owes its growth in the ranking by 2 positions mainly to a drop of the share of inactive population by 7 p.p. and decrease of the NEET rate by 8 p.p. Still, in the course of 15 years Estonia improved its position by 2 points mainly due to a drop in inactive population by 8 p.p. and a rise in labour productivity by 17 p.p. At the 
same time the first rating group was left by Slovenia (a drop by 4 points), in which - as the only analysed CEE country - labour productivity fell by 2 p.p. The reason could be a serious influence of the crisis in Slovenian economy. The crisis in Slovenian banking sector substantially contributed to a recession in that country (Feldmann, 2017). The second rating group included such countries as Hungary, Slovenia and Lithuania. That group was abandoned by Latvia, whose position fell in the ranking by 1 point. The third rating group included Latvia and Romania. In 2019 the worst situation on the labour market among the analysed CEE countries was in Bulgaria, Croatia and Slovakia. As it has already been mentioned, Bulgaria's and Slovakia's positions were stationary. At the same time, Croatia's ranking position deteriorated by 2 points, which was due to a very low improvement of labour market indicators.

Other researchers conducted similar analyses using taxonomic methods. For example, Warzecha evaluated changes on CEE labour markets using the Hellwig's method (Warzecha, 2018). Although her study took into account a slightly different set of variables, they also applied to the labour market situation (the years taken for analysis were 2005 and 2016). The positions of CEE countries in rankings by Hellwig's synthetic measure were similar to those presented in this study. For example, in both studies, Slovenia was at the bottom of the ranking lists. Poland, from the end of the rankings (in 2004 and 2005), advanced to the second positions (in 2016 and 2019). It should be noted that when comparing the research results even a small change in the set of diagnostic variables affects the ranking positions of the analysed objects (Jarocka, 2013).

\section{GDP and employment in CEE countries (regression analysis)}

The aim of the second stage of analyses was the differentiation analysis of CEE countries in terms of employment. Moreover, the authors undertook to investigate into the relationship between the labour market situation expressed in terms of the number of the employed (dependent variable) and GDP (independent variable). They posed the following research question: does a change in GDP have a significant impact on a change in the number of the employed in the analysed countries?

In order to conduct an initial analysis of relationships between the employment volume and GDP, the authors made a graphic comparison of these values. Figure 2 shows the dynamics of changes in average GDP values (constant prices) and the average number of the employed in the analysed CEE countries $(2004=100)$.

Compared to 2004, the average value of GDP increased by over 90 p.p., while the average number of employed persons in the analysed countries did not change significantly compared to the base year. In 2019, this value was $106.3 \%$ of the value from 2004 . The number of employees showed an upward trend, except for 2011-2013.

It is worth mentioning that in 2009 , due to the influence of economic crisis on the labour market, both a significant drop in GDP as well as in employment was observed - Figure 3. Poland was not alone in this situation as no European country escaped the recession (Lallement, 2011; Moszyński, 2013).

Analysing the relation between two variables - average changes in the number of the employed and average changes of GDP in CEE countries in the years 2004-2009, a positive relation can be noticed - Figure 4 . 


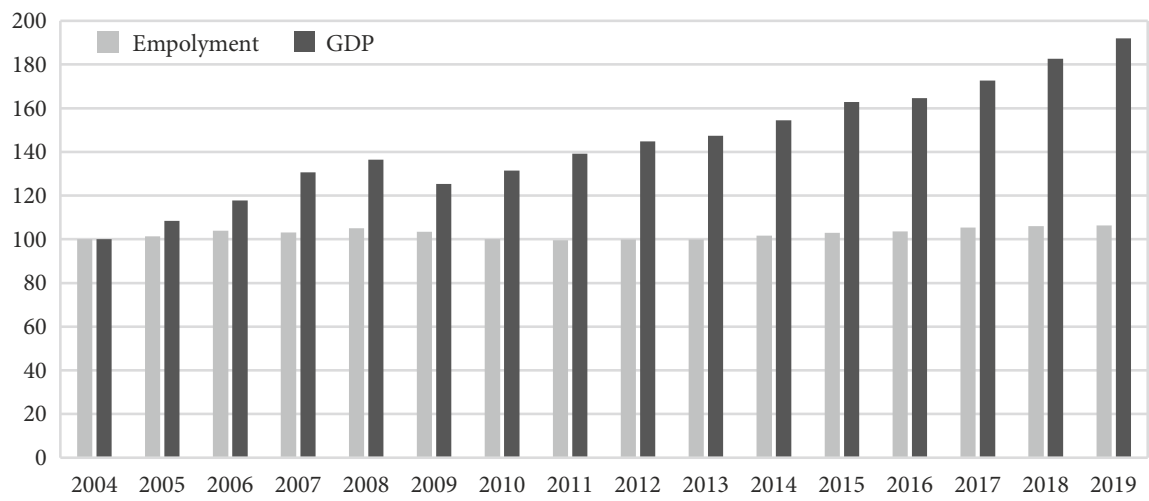

Figure 2. Dynamics of changes in average GDP values (constant prices, EUR) and the average number of the employed in the analysed CEE countries $(2004=100)$

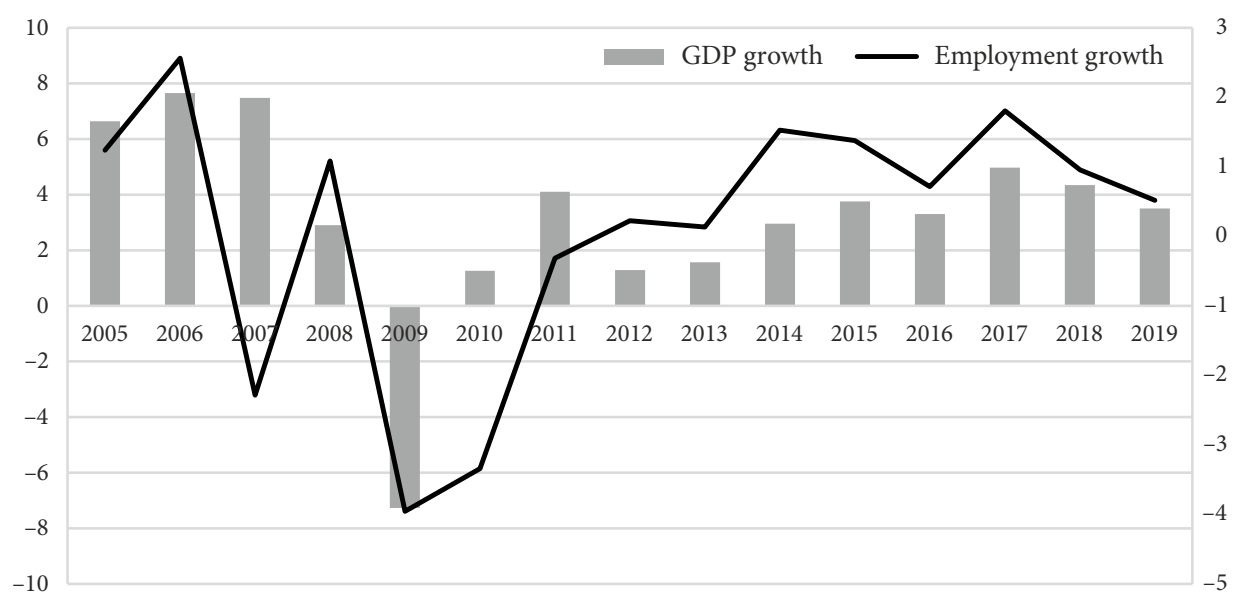

Figure 3. Growth of employment and GDP in CEE countries in years 2004-2019

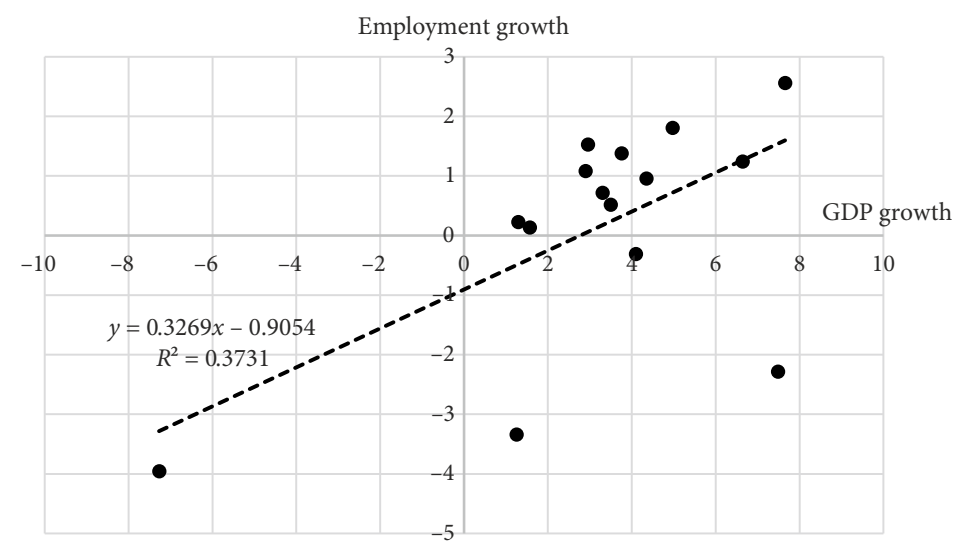

Figure 4. Relationship between average changes in the number of employees and average changes in GDP in CEE countries (2004-2019) 
It follows from Figure 4 that there exists a positive correlation between growth rates of the analysed macroeconomic variables; therefore, positive growth rates of the number of the employed generally occur in the presence of positive growth rates of GDP. That tendency can be connected with Okun's law, which postulates a negative relationship between movements of the unemployment rate and real GDP (Okun, 1962; Sögner \& Stiassny, 2000; Guisinger et al., 2015; Zhofchinova \& Grabowska, 2019; Pizzo, 2020).

In order to analyse the impact of changes in GDP on the number of the employed in individual countries, 11 models (9) were built and verified. The models were constructed on the basis of quarterly data from the years 2004-2019. The results of the estimation and verification are presented in the Table 5.

Based on the model estimation results obtained in the table, it can be concluded that all parameters for the explanatory variable $\left(S_{Y_{t}}\right)$ are statistically significant in the sense of Student's $t$-statistics at the significance level of 0.05 . This is also evidenced by the values of their mean estimation errors. The values of the $F$ statistics and the corresponding $p$ probability levels confirm the statistical significance of linear models. However, despite this - according

Table 5. Results of the estimation and verification of models

\begin{tabular}{|c|c|c|c|c|c|c|c|}
\hline Country & \multicolumn{2}{|c|}{$\begin{array}{l}\text { Value of } \\
\text { parameters }\end{array}$} & $\begin{array}{l}\text { Average } \\
\text { error of } \\
\text { estimate }\end{array}$ & $t(61)$ & $p$-value & $R^{2}$ & $\begin{array}{c}F \\
(p \text {-value })\end{array}$ \\
\hline \multirow{2}{*}{ Bulgaria } & $a$ & -0.19 & 0.25 & -0.41 & 0.4614 & \multirow{2}{*}{0.5076} & \multirow{2}{*}{$\begin{array}{c}62.885 \\
p<0.00000\end{array}$} \\
\hline & $b$ & 0.13 & 0.02 & 7.930 & 0.0000 & & \\
\hline \multirow{2}{*}{ Czechia } & $a$ & 0.07 & 0.06 & 1.185 & 0.2406 & \multirow{2}{*}{0.5610} & \multirow{2}{*}{$\begin{array}{c}77.966 \\
p<0.00000\end{array}$} \\
\hline & $b$ & 0.08 & 0.01 & 8.830 & 0.0000 & & \\
\hline \multirow{2}{*}{ Estonia } & $a$ & -0.19 & 0.24 & -0.805 & 0.4238 & \multirow{2}{*}{0.3117} & \multirow{2}{*}{$\begin{array}{c}27.627 \\
p<0.00000\end{array}$} \\
\hline & $b$ & 0.18 & 0.03 & 5.256 & 0.0000 & & \\
\hline \multirow{2}{*}{ Croatia } & $a$ & -0.09 & 0.24 & -0.371 & 0.7117 & \multirow{2}{*}{0.5353} & \multirow{2}{*}{$\begin{array}{c}70.286 \\
p<0.00000\end{array}$} \\
\hline & $b$ & 0.20 & 0.02 & 8.384 & 0.0000 & & \\
\hline \multirow{2}{*}{ Latvia } & $a$ & -0.43 & 0.19 & -2.220 & 0.0302 & \multirow{2}{*}{0.4697} & \multirow{2}{*}{$\begin{array}{c}54.041 \\
p<0.00000\end{array}$} \\
\hline & $b$ & 0.15 & 0.02 & 7.351 & 0.0000 & & \\
\hline \multirow{2}{*}{ Lithuania } & $a$ & -0.33 & 0.16 & -2.038 & 0.0459 & \multirow{2}{*}{0.4781} & \multirow{2}{*}{$\begin{array}{c}55.897 \\
p<0.00000\end{array}$} \\
\hline & $b$ & 0.12 & 0.02 & 7.476 & 0.0000 & & \\
\hline \multirow{2}{*}{ Hungary } & $a$ & 0.08 & 0.12 & 0.678 & 0.5003 & \multirow{2}{*}{0.3406} & \multirow{2}{*}{$\begin{array}{c}31.512 \\
p<0.00000\end{array}$} \\
\hline & $b$ & 0.07 & 0.01 & 5.614 & 0.0000 & & \\
\hline \multirow{2}{*}{ Poland } & $a$ & 0.20 & 0.17 & 1.203 & 0.2337 & \multirow{2}{*}{0.1591} & \multirow{2}{*}{$\begin{array}{c}11.542 \\
p<0.00120\end{array}$} \\
\hline & $b$ & 0.06 & 0.02 & 3.397 & 0.0012 & & \\
\hline \multirow{2}{*}{ Romania } & $a$ & -0.31 & 0.35 & -0.873 & 0.3863 & \multirow{2}{*}{0.2111} & \multirow{2}{*}{$\begin{array}{c}51.504 \\
p<0.00000\end{array}$} \\
\hline & $b$ & 0.07 & 0.02 & 4.041 & 0.0002 & & \\
\hline \multirow{2}{*}{ Slovenia } & $a$ & -0.09 & 0.16 & -0.581 & 0.5636 & \multirow{2}{*}{0.4578} & \multirow{2}{*}{$\begin{array}{c}51.504 \\
p<0.00000\end{array}$} \\
\hline & $b$ & 0.18 & 0.02 & 7.177 & 0.0000 & & \\
\hline \multirow{2}{*}{ Slovakia } & $a$ & 0.17 & 0.11 & 1.618 & 0.1108 & \multirow{2}{*}{0.3090} & \multirow{2}{*}{$\begin{array}{c}27.280 \\
p<0.00000\end{array}$} \\
\hline & $b$ & 0.08 & 0.02 & 5.223 & 0.0000 & & \\
\hline
\end{tabular}


to the authors - the interpretation of the estimates requires great caution. This is due to the fact that the intercepts in the estimated models (except for the Latvian and Lithuanian model) do not significantly equal zero. Therefore, the authors of the paper do not undertake their interpretation. Moreover, the highest value of the determination coefficient obtained is $56 \%$, which proves that the change in the number of employed persons is influenced by factors other than the GDP growth rate.

However, when analysing the estimation results, it can be stated that in the analysed countries the situation differs. While analysing data in Table 5 it can be concluded that changes in GDP affected changes in the number of the employed in such countries as: Bulgaria, Czechia and Croatia (for these countries the coefficient of determination was the highest). Still, GDP had the smallest impact on the employment level in Poland and Romania. In countries for which the coefficient of determination assumed the lowest values, the number of the employed was affected by other factors, e.g. labour costs, industrial structure observed within the regions (Nazarko \& Chodakowska, 2017; Johnston \& Huggins, 2018), a wage level (Kolevi \& Tsoklinova, 2018) or the effect of the fluctuation of exchange rates (Morina et al., 2020).

\section{Conclusions}

Having comparable background during the socialist period, CEE countries analysed in the paper entered the transition process with similar social and economic conditions. However, those countries have undergone different institutional transformations and separate paths of economic reforms during their transition.

The multidimensional nature of labour markets entails the use of synthetic indicators to present its diversity (Rollnik-Sadowska et al., 2020). For the analysis of labour markets diversity the authors used both taxonomic methods as well as econometric modelling.

The conducted analysis proves that CEE countries are diversified not homogeneous when it comes to the labour market situation. Moreover, the position of CEE countries on the labour market is very changeable. The crucial period for the analysis was joining the EU by the first CEE countries. In 2004 the dominant economy with regard to labour market situation was Slovenia, the worst situation was observed in Poland and Slovakia. However, after 15 years of participation in the EU framework that situation changed significantly. Currently, the best labour market situation exists in Czechia, Poland and Estonia, and the worst still in Slovakia. Top CEE labour markets owe their success to cooperation with economically strong neighbouring economies (Czechia and Poland with Germany and Estonia with Finland). Nevertheless, even if those countries are in the same rating group they have a different development path which improves their labour market situation.

The Czechs owe this success to growing production, forcing growth in wages as well as the development of key industries and supporting small entrepreneurship. The country's economic success is based primarily on stable exports, especially of cars and machines. Estonia attracts investors through a unique tax system. That country develops digitalization and decentralizes its institutions. The Polish situation is a bit different as significant improvement in the labour market situation (considerable drop of unemployment rate) can be caused by external migration of Polish inhabitants (Żołędowski, 2020). That thesis was supported by 
regression results where $R^{2}$ for Poland is very low, hence the GDP growth does not influence a growth in employment.

Future research should focus on deepening the analysis of the causes of differentiation in the labour markets in CEE countries by conducting qualitative research among various stakeholders of the labour market (e.g. employers, employees, unemployed, representatives of public employment services) as well as national documents analysis.

\section{Funding}

The paper was founded by resources of Faculty of Engineering Management, Bialystok University of Technology (works number: WI/ WIZ-INZ/1/2020 and W/WIZ/1/2019).

\section{Author contributions}

The paper is a result of a collaborative work.

\section{Disclosure statement}

Authors do not have any competing financial, professional, or personal interests from other parties. The authors declare no conflict of interest.

\section{References}

Behzadian, M., Otaghsara, S. K., Yazdani, M., \& Ignatius, J. (2012). A state-of the-art survey of TOPSIS applications. Expert Systems with Applications, 39, 13051-13069. https://doi.org/10.1016/j.eswa.2012.05.056

Brejc, M., \& Diamantopoulou, A. (2000). Joint assessment of the employment policy priorities of Slovenia. The European Commision and the Government of Slovenia.

Cazes, S., \& Nesporova, A. (2003). Labour markets in transition: balancing flexibility and security in Central and Eastern Europe. ILO, Geneva. https://doi.org/10.3917/reof.075.0023

de Koning, J. (Ed.). (2007). Employment and training policies in Central and Eastern Europe. A transitional labour market perspective. Dutch University Press.

Džunić, M., Stanković, J., \& Janković-Milić, V. (2018). Multi-criteria approach in evaluating contribution of social entrepreneurship to the employment of socially-excluded groups. Technological and Economic Development of Economy, 24(5), 1885-1908. https://doi.org/10.3846/20294913.2017.1347906

Ertman, A. (2011). Zróżnicowanie elastyczności rynków pracy w wybranych krajach europejskich oraz USA w świetle metody TOPSIS (Differences in flexibility of labour markets in OECD countries the TOPSIS method). Oeconomia Copernicana, 3, 43-64. https://doi.org/10.12775/OeC.2011.012

European Commission. (2019). 2019 European Semester: Assessment of progress on structural reforms, prevention and correction of macroeconomic imbalances, and results of in-depth reviews under Regulation (EU) No 1176/2011 (Country Report Poland 2019, Commission Staff Working Document). https://eur-lex.europa.eu/legal-content/EN/ALL/?uri=CELEX:52019SC1020

Fedajev, A., Nikolic, D., Radulescu, M., \& Sinisi, C. I. (2019). Patterns of structural changes in CEE economies in new millennium. Technological and Economic Development of Economy, 25(6), 13361362. https://doi.org/10.3846/tede.2019.11253 
Feldmann, M. (2017). Crisis and opportunity: varieties of capitalism and varieties of crisis responses in Estonia and Slovenia. European Journal of Industrial Relations, 23(1), 33-46. https://doi.org/10.1177/0959680116672280

Giudici, P. (2003). Applied data mining. Statistical methods for business and industry. John Wiley \& Sons Ltd.

Guisinger, A. Y., Hernandez-Murillo, R., Owyang, M., \& Sinclair, T. M. (2015). A statelevel analysis of Okun's Law (FEDL Working Paper No. 2015-029A). Federal Reserve Bank. https://doi.org/10.26509/wp-201523

Hutengs, O., \& Stadtmann, G. (2014). Don't trust anybody over 30: youth unemployment and Okun's law in CEE countries. Bank i Kredyt, 45(1), 1-16.

Hwang, C. L., \& Yoon, K. (1981). Multiple attribute decision making. Springer-Verlag. https://doi.org/10.1007/978-3-642-48318-9

Jarocka, M. (2013). Wpływ metody doboru cech diagnostycznych na wynik porządkowania liniowego na przykładzie rankingu polskich uczelni. Prace Naukowe Uniwersytetu Ekonomicznego we Wrocławiu, Taksonomia, 21(279), 85-94.

Johnston, A., \& Huggins, R. (2018). Regional growth dynamics in the service sector: The determinants of employment change in UK regions, 1971-2005. Growth and Change, 49(1), 71-96. https://doi.org/10.1111/grow.12221

Kolevi, K., \& Tsoklinova, M. (2018). Determinants of employment in Bulgaria. In RTU 59th International Scientific Conference on Economics and Entrepreneurship SCEE'2018 Proceedings (pp. 48-53), Riga Technical University.

Kotlorz, D., \& Sojka, E. (2017). Wzrost gospodarczy a zatrudnienie w Polsce w latach 1995-2014. Studia prawno-ekonomiczne, 105, 259-275.

Kukuła, K. (2000). Metoda unitaryzacji zerowej. Państwowe Wydawnictwo Naukowe.

Lallement, M. (2011). Europe and the economic crisis: forms of labour market adjustment and varieties of capitalism. Work, Employment and Society, 25(4), 627-641.

https://doi.org/10.1177/0950017011419717

Lipták, K. (2013). The labour market situation in the Central-Eastern European region - towards a new labour paradigm. Journal of Geography and Geology, 5(3), 88-100.

https://doi.org/10.5539/jgg.v5n3p88

Młodak A. (2006). Analiza taksonomiczna $w$ statystyce regionalnej. Difin.

Mohaghar, A., Mahbanooei, B., Behnam, M., \& Khavari, Z. (2018). Analyzing OECD’s labor market efficiency in 2018. In 34th International Scientific Conference on Economic and Social Development - XVIII International Social Congress (ISC-2018) (pp. 341-353), Varazdin Development and Entrepreneurship Agency, Moscow.

Morina, F., Hysa, E., Ergün, U., Panait, M., \& Voica, M. C. (2020). The effect of exchange rate volatility on economic growth: case of the CEE countries. Journal of Risk and Financial Management, 13(8), 177. https://doi.org/10.3390/jrfm13080177

Moszyński, M. (2013). Labor markets in the Central and Eastern European Countries during the Economic Downturn. In A. P. Balcerzak (Ed.), Labour markets in the global financial crisis. Polish Economy Branch in Toruń.

Nazarko, J., \& Chodakowska, E. (2017). Labour efficiency in construction industry in Europe based on frontier methods: data envelopment analysis and stochastic frontier analysis. Journal of Civil Engineering and Management, 23(6), 787-795. https://doi.org/10.3846/13923730.2017.1321577

Novák, Z. (2020). Structural change in Central and South Eastern Europe-does technological efficiency harm the labour market? Sustainability, 12(11), 4704. https://doi.org/10.3390/su12114704

Okun, A. M. (1962). Potential GNP: its measurement and significance. In Proceedings of the Business and Economics Statistics (pp. 98-104). American Statistical Association. 
Pietrzak, M. B. (2016). Application of TOPSIS method in condition of the presence of spatial dependence (Working Papers No. 38). Institute of Economic Research (IER), Torun.

Pilc, M. (2015). Determinants of the labour market institutions in post-socialist economies. Communist and Post-Communist Studies, 48, 97-112. https://doi.org/10.1016/j.postcomstud.2015.06.008

Pizzo, A. (2020). Literature review of empirical studies on Okun's law in Latin America and the Caribbean (Employment Working Paper No. 252). International Labour Office, Geneva.

Revenga, A. L., \& Bentolila, S. (1995). What affects the employment rate intensity of growth? (Banco de España - Servicio de Estudios Documento de Trabajo No. 9517). https://core.ac.uk/download/ pdf/322620489.pdf

Roaf, J., Atoyan, R., Joshi, B., \& Krogulski, K. (2014). 25 years of transitionpost-communist Europe and the IMF (Regional Economic Issues Special Report). International Monetary Fund. https://doi.org/10.5089/9781498305631.086

Rollnik-Sadowska, E. (2014). Model WellBox - możliwości realizacji na polskim rynku pracy (na przykładzie Klubów Integracji Społecznej w Łapach i Zabłudowie). Problemy Polityki Społecznej. Studia i Dyskusje, 26, 155-167.

Rollnik-Sadowska, E. (2016, May 19-20). Labour markets in the central and eastern Europe - comparative analysis. In 21st International Scientific Conference on Smart and Efficient Economy (pp. 387-393), Brno, Czech Republic.

Rollnik-Sadowska, E., Jarocka M., \& Dąbrowska, E. (2020). Diversity of regional labour markets in Poland. European Research Studies Journal, 23(4), 33-51. https://doi.org/10.35808/ersj/1670

Shih, H.-S., Shyur, H.-J., \& Lee, E. S. (2007). An extension of TOPSIS for group decision making. Mathematical and Computer Modelling, 45, 801-813. https://doi.org/10.1016/j.mcm.2006.03.023

Sikulova, I., \& Frank, K. (2014). Transition to market economy in the Central and Eastern European countries - comparative analysis. European Scientific Journal, 1, 544-554.

Sögner, L., \& Stiassny, A. (2000). A cross-country study on Okun's law (Working Papers Series: Growth and Employment in Europe: Sustainability and Competitiveness No. 13, pp. 1-24). Vienna University of Economics and Business Administration.

Stanimir, A. (2020). Generation Y on labour market? perception of work values and quality of job, International Journal of Economic Sciences, 1, 202-223. https://doi.org/10.20472/ES.2020.9.1.011

Strzała K., \& Przechlewski, T. (1994). Ekonometria inaczej. Wydawnictwo Uniwersytetu Gdańskiego, Gdańsk.

Svejnar, J. (2002). Labour market flexibility in Central and East Europe (William Davidson Working Paper No. 496, pp. 1-26). University of Michigan Business School.

Szalai, J. (2002). From opposition in private to engagement in public: motives for citizen participation in the post-1989 democracies of Central Europe. Social Research, 69(1), 71-82.

Veebel, V., Namm, A., \& Tillmann, T. (2014). Testing the myths of transition: was estonia following the shock therapy model and Slovenia following the gradualist model in 1991-2000? Studies of Transition States and Societies, 6(2), 5-21.

Warzecha, K. (2018). Taxonomic analysis of changes on labour markets in Central and Eastern Europe countries. In Proceedings of 18th International Joint Conference Central and Eastern Europe in the Changing Business Environment (pp. 492-501), Bratislava, Slovakia and Prague, Czech Republic.

Winiecki, J. (2008). Employment and unemployment in transition: the legacy of the communist past. Post-Communist Economies, 20, 377-390. https://doi.org/10.1080/14631370802281480

Zhofchinova, V., \& Grabowska, Z. (2019). Problems of unemployment through the employment policy in the labour market: the case of the Slovak Republic and the Czech Republic. Public Administration Issues, 5, 103-119. https://doi.org/10.17323/1999-5431-2019-0-5-103-119

Żołędowski, C. (2020). Poland in international migrations: the perspective of world systems theory. Miscellanea Geographica, 24(2), 94-103. https://doi.org/10.2478/mgrsd-2020-0005 